\title{
The Colosseum in the film «Roman Holiday» (1953)
}

\author{
Turchynova Ganna
}

Candidate of Pedagogic Sciences, Associate Professor

Dragomanov National Pedagogical University

Pet'ko Lyudmila

Candidate of Pedagogic Sciences, Associate Professor

Dragomanov National Pedagogical University

\section{Grigoruk Valeria}

Student of Faculty of Natural and Geographical Education and Ecology

Dragomanov National Pedagogical University

"While stands the Coliseum, Rome shall stand; When falls the Coliseum, Rome shall fall; And when Rome falls - the World."

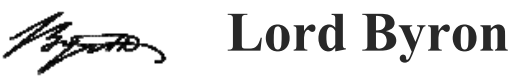

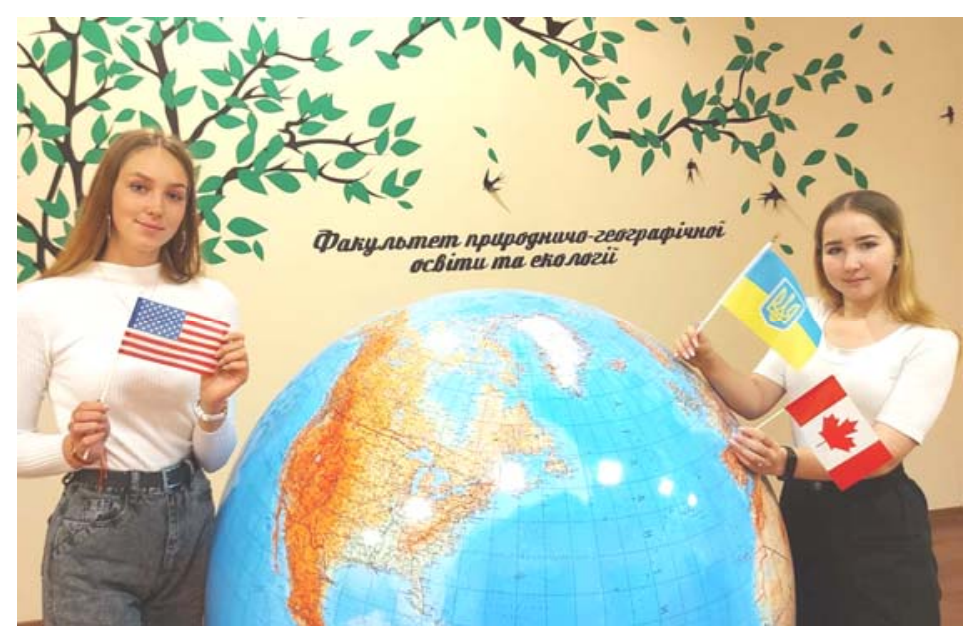

Fig. 1. Students A. Melnychuk [29] and V. Grigoruk.

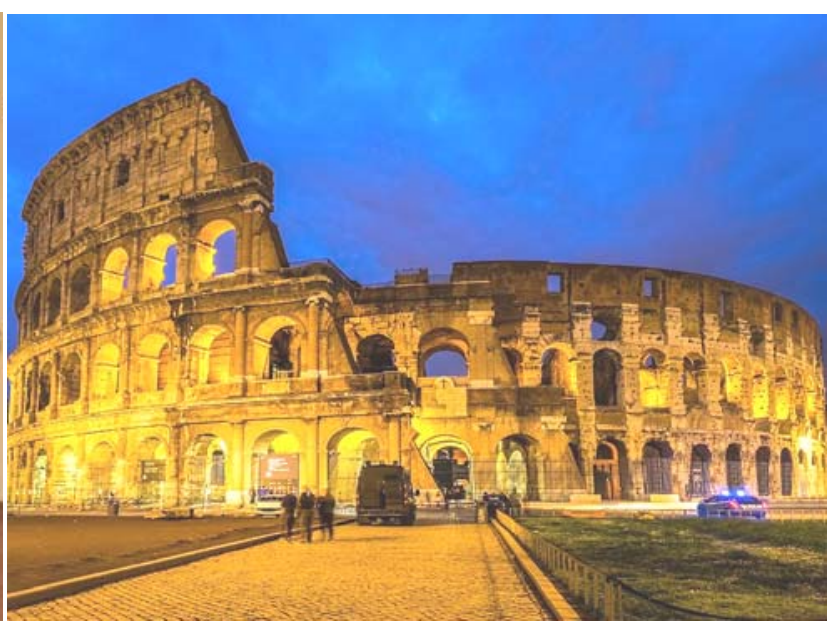

Fig. 2. The Colosseum, Rome (Italy).

\begin{abstract}
This article is dedicated to the Colosseum and a classic movie filmed in Rome "Roman Holiday" (1953, USA). It was the first Hollywood film to be filmed and processed entirely in Italy. The great thing about Rome is that not much changes in the historic city centre. The story is about princess Ann (played by Audrey Hepburn) who comes to Rome and slips out one evening from the Embassy, and an American journalist (Gregory Peck). Joe takes Ann around Rome for a "Grand Day Out" and we have loads of views of Rome, both the famous monuments and the streets, squars, and bridges. So when Audrey Hepburn surveys the Colosseum, she's really surveying the Colosseum.
\end{abstract}


In the film "Roman Holiday", Princess Ann holds on tight as they race through the roads past the famous Colosseum. The stars riding a Vespa made an iconic movie poster for the film, during an important era for Italian filmmaking.

The authors of the article offer an innovative approach to the formation of a professionally oriented foreign language learning environment by studying the filming locations of the masterpiece of world cinema "Roman Holiday" (1953, USA), on the example of the Colosseum. It is a typical example copied throughout the empire: a highly decorative exterior, seats set over a network of barrel vaults, and underground rooms below the arena floor to hide people, animals and props until they were needed in the spectacles of the"Theatre of Death".

Rememered the greatest English historian of all time Bede, Lord Byron's poem"Childe Harold's Pilgrimage", gladiators.

Key words: university, professionally oriented foreign language learning environment, students, "Roman Holiday" (1953, USA), the Colosseum, St. Bede the Venerable, "Childe Harold's Pilgrimage" by Lord Byron, gladiators.

Roman Holiday (1953, USA) is a classic movie filmed in Rome. The great thing about Rome is that not much changes in the historic city centre. We can see the same things today as tourists could in the 1950s when this movie was made (movie [34]).

Our student project group is studying the filming locations $[9 ; 12 ; 13 ; 24 ; 25$; $28 ; 29 ; 58 ; 59]$. Our paper is dedicated to the Colosseum (Fig. 1), see videos [46; 2].

With Rome as the backdrop, Audrey Hepburn's Princess Ann rendezvoused with adventure, freedom and romance in the 1953 mega flick Roman Holiday (1953).

The story is about princess Ann (played by Audrey Hepburn) who comes to Rome and slips out one evening from the Embassy, and an American journalist (Gregory Peck) who spots her lying on the bench at night but doesn't recognize her at first, takes her home and puts Ann to bed in his flat. The next morning he's discovered who she is and realizes he's got a story on his hands [55], video [37].

Joe takes Ann around Rome for a "Grand Day Out" and we have loads of views of Rome, both the famous monuments and the streets, squars, and bridges as they zip around the city on a Vesta scooter [55] (Fig. 3, 4, 5, 6).

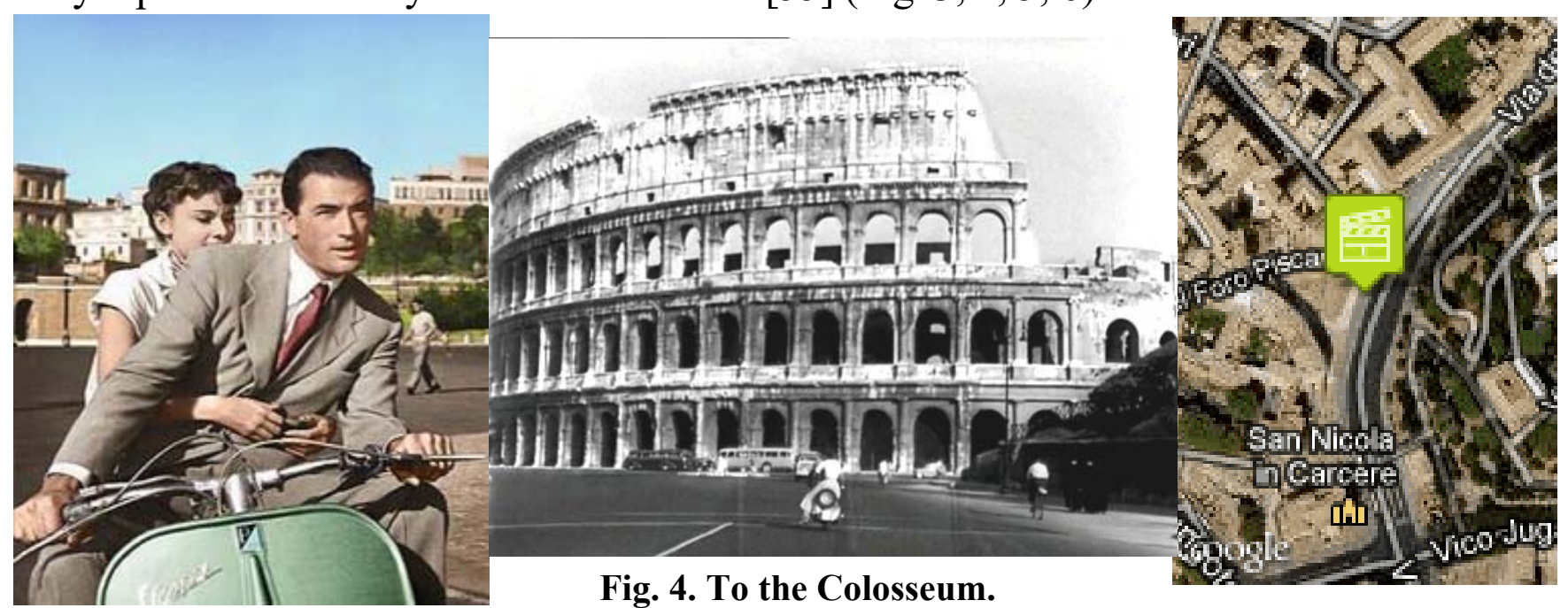

Fig. 3. On a Vesta scooter (Roman Holiday, 1953).

Fig. 5. The Colosseum on the map. 
The Colosseum can never be too far away when we're in Rome, so of course the largest amphitheatre in the world makes an appearance in the lives of our one-day lovers. Its 2,000-year-old history weaves in the glory of an invincible architecture and the violence of gladiator battles and animal hunts [42]. It's one of the symbols of Rome.

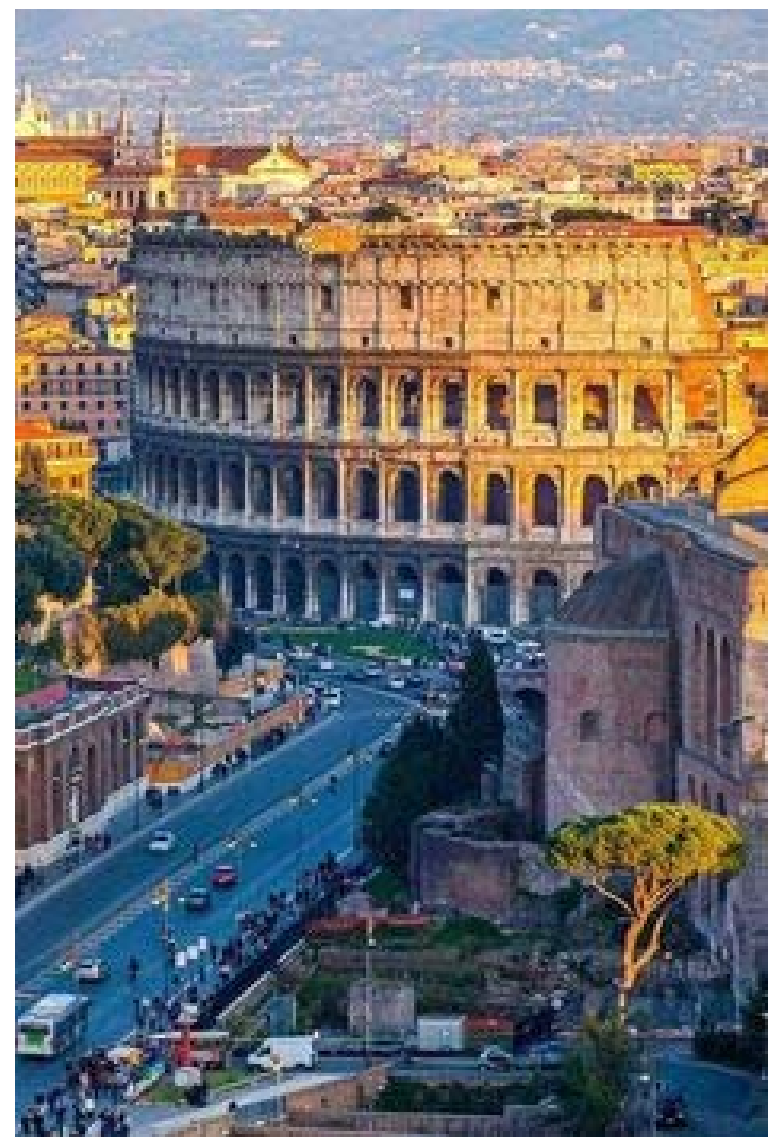

Fig. 6. Via dei Fori Imperiali and the Colosseum.

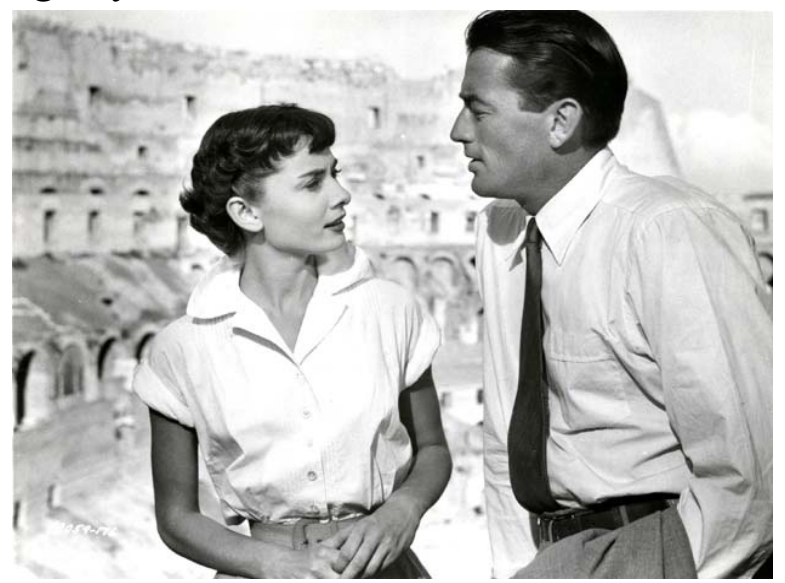

Fig. 7. Audrey Hepburn and Gregory Peck (1953).

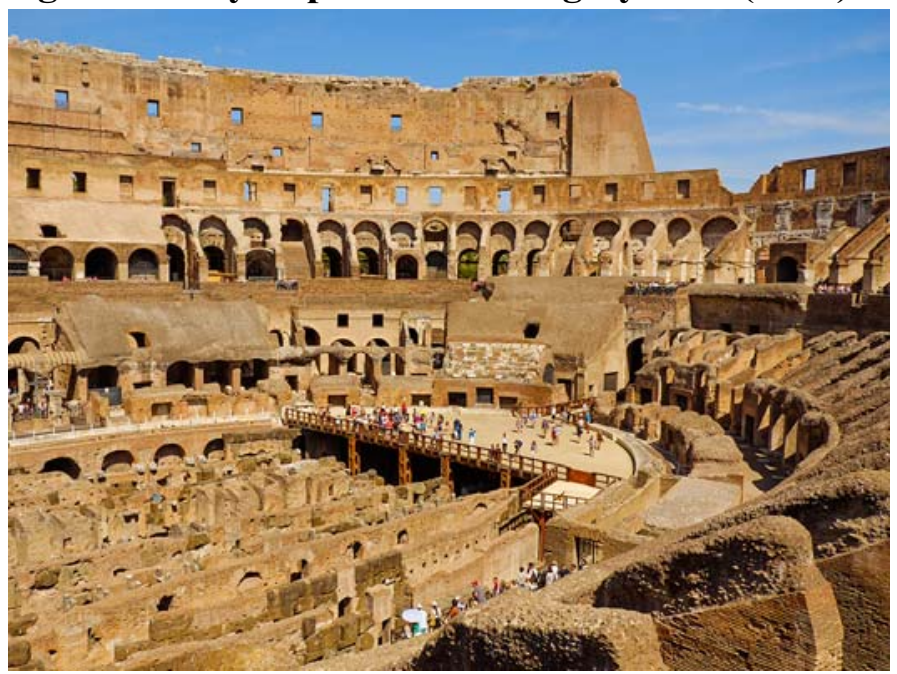

Fig. 8. Interior of the Colosseum.

At the beginning of the mentioned episode from the film Roman Holiday (1953) Irving (Fig. 9) failed to gain a strict answer to the upcoming destination of Joe and Anne (see the video [38]), yet the scene is being passed into another one on the motorbike. (And some words about Joe's friend Irving. More than just generating keepsakes, Eddie Albert also provides valuable humor to the film's already bubbly surface. We "always get a kick out of Joe spilling his drink on Irving to prevent him from spilling any beans,... also enjoy his guerrilla style of picture taking, such as driving a car while taking shots (this actually mirrors Wyler's shooting style as well) [40]).

The movie duet passes the Teatro Marcello, an ancient theater with a history of two thousand years, often misregarded as the Coliseum. This city landmark is located within easy distance to Piazza

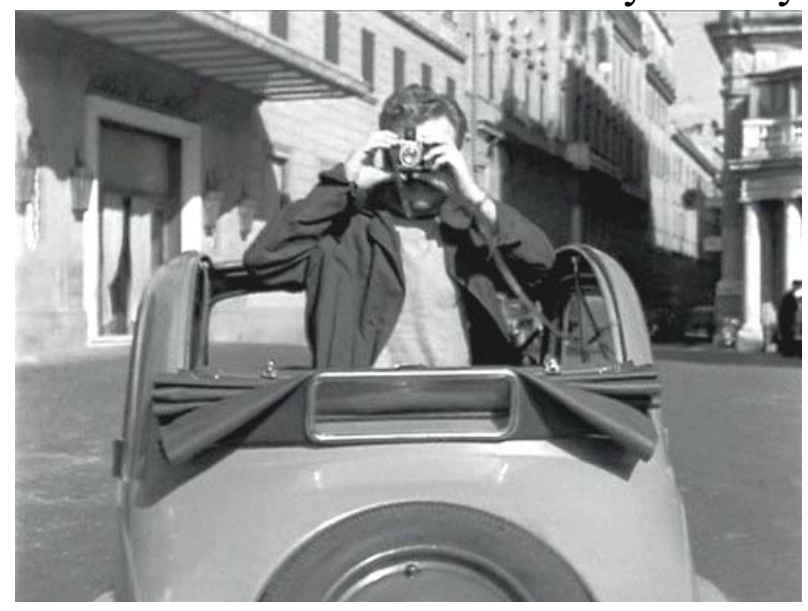

Fig. 9. Eddie Albert as Irving (Roman Holiday, 1953). 
Venezia square. The background panorama of the upcoming scenes includes a part of Vittoriano (Vittorio Emanuele II Monument) far behind (Fig. 10).

Finally, another shift of the camera interspaces the shot with a magnificent Coliseum, a world-wide recognized landmark of Rome, a reminder of the once vanished glory of the Roman Empire. The scene takes Joe and Anne from behind, all while they are moving along Via Dei Fori Imperiali (Fig. 4, 5, 6, 10) up to the

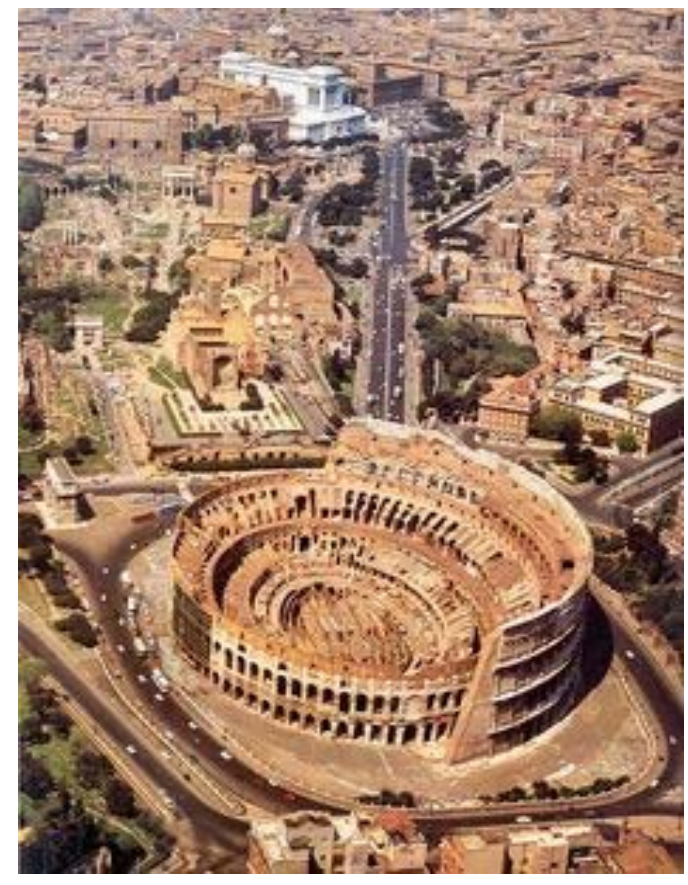

legendary arena. A movie visit to Coliseum turns out to be a source of some breathtaking panoramas with the best inner dimensions and angles of the arena, had once seats for 50000 people [4]. (Fig. 8, 10, 11), see the video [6].

The movie trio then makes a pit stop at the Colosseum. Like many of the structures in Rome the pictures we see do not do it justice, but Roman Holiday (1953) comes close to capturing its sheer immensity (Fig. 4, 6, 8, 10, 11), see the video [1].

In the days before computer-generated images, real men tore each other apart, and this is where they did it. The largest amphitheater in the world had just a few strategically placed tourists in it when a guide explained its 2,000-year

Fig. 10. Via Dei Fori Imperiali. history to Princess Ann and Joe [44]. (Fig.7,8,11, 12,13, 14). We can see a truly wonderful movie starring Gregory Peck and Andrey Hepburn. It was the first Hollywood film to be filmed and processed entirely in Italy. So when Audrey Hepburn surveys the Colosseum, she's really surveying the Colosseum [41], see the video [33].
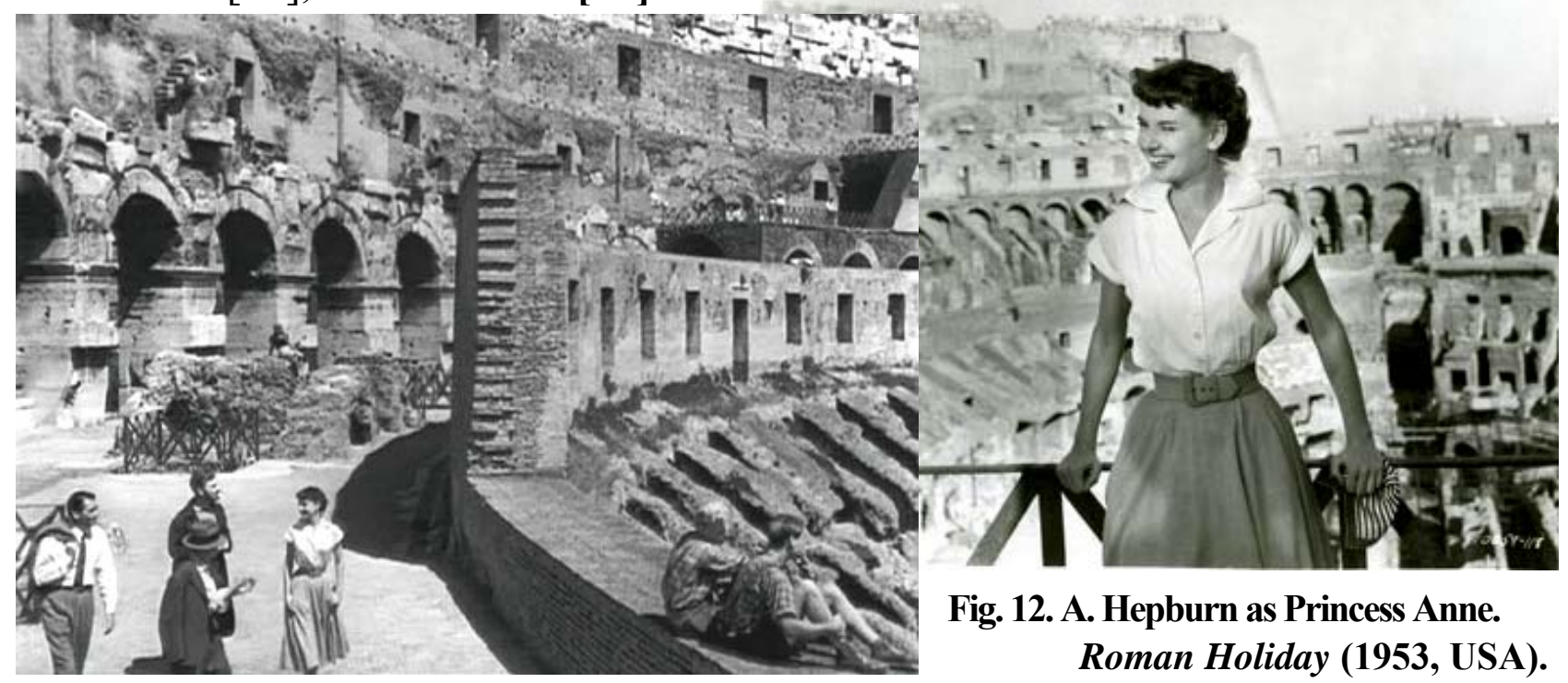

Fig. 12. A. Hepburn as Princess Anne. Roman Holiday (1953, USA).

Fig. 11. Roman Holiday (1953, USA). Ann. Joe, and Irving inside the Colosseum.

From the script of the movie "Roman Holiday" (1953). In the city, Joe drives along the streets on a little Vespa scooter; Princess Ann riding side-saddle on the 
back, her arms wrapped around his waist (Fig. 3, 4, 32). She looks out smiling at the sights as they drive to the Colliseum, looming up before them. They walk inside the Colliseum, accompanied by a guide who points to the structure, instructing Ann (Fig. 9, 11, 14). Joe follows just behind them, being joined now by Irving (Fig. 14). They walk to the edge, looking down over the centre of the structure. Ann listens to guide, watched on by Joe and Irving who lights up a cigarette. Holding the lighter,Irving signals secretly to Joe who acknowledges him with a private signal of his own. Back on the streets of Rome and Joe and Ann ride along on the scooter, followed by Irving in a small open-topped car. Irving overtakes them and, as Joe points out the sights to Ann, he takes pictures out of the back of the vehicle, barely regaining control of the vehicle afterwards [39], see the video [45].
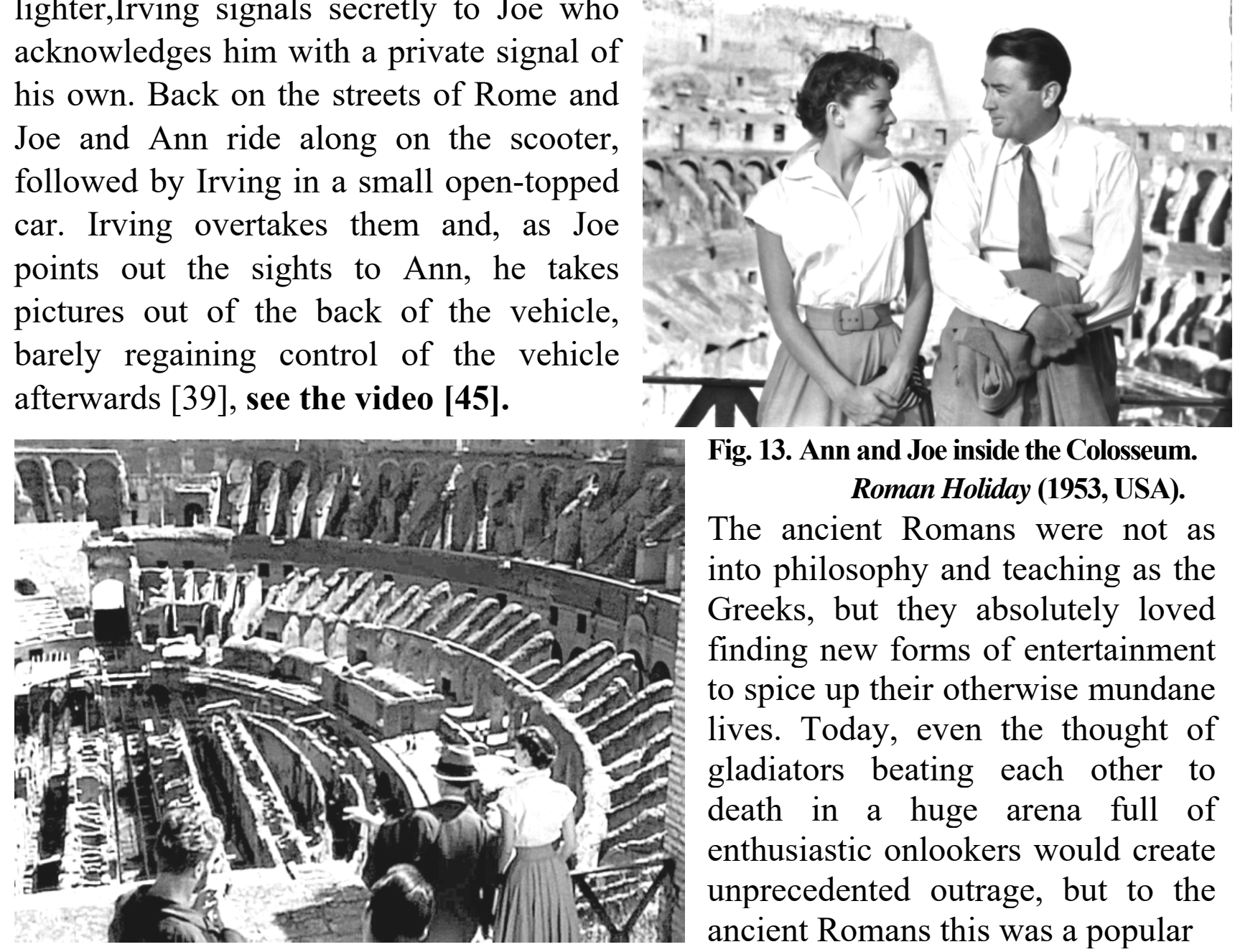

Fig. 13. Ann and Joe inside the Colosseum. Roman Holiday (1953, USA).

The ancient Romans were not as into philosophy and teaching as the Greeks, but they absolutely loved finding new forms of entertainment to spice up their otherwise mundane lives. Today, even the thought of gladiators beating each other to death in a huge arena full of enthusiastic onlookers would create unprecedented outrage, but to the ancient Romans this was a popular Fig. 14. Roman Holiday (1953, USA). The Colosseum. and common form of entertainment.
However, despite the short life expectancy, being a gladiator was in many ways one of the most glamorous professions in ancient Rome. Gladiator battles would draw thousands of spectators, including the biggest names in contemporary Roman society (see video [53]), Fig. 15, 16.

The Colosseum, is not only the symbol of the city but is also one of the most famous monuments in the world, was started by Vespasiano but finished by Tito in $80 \mathrm{AD}$ and opened to the public with a special inauguration 100 days long. It was constructed to give Rome a place worthy of its famous Gladiators Games [35; 15].

In order to honor the most popular of these ancient Roman superstars, here is the list of the top 10 ancient Roman gladiators [53; 45 (text)], Fig. 18.

The Romans were very blood thirsty, especially when it came to entertainment. It is estimated that 500,000 men and over 1 million animals were killed in the Colosseum. Archaeologists have spent years on the excavation and preservation of 
the hypogeum, the under-floor complex where gladiators trained and animals were raised with lifts, above [20], (Fig. 15, 17), see the video [5].

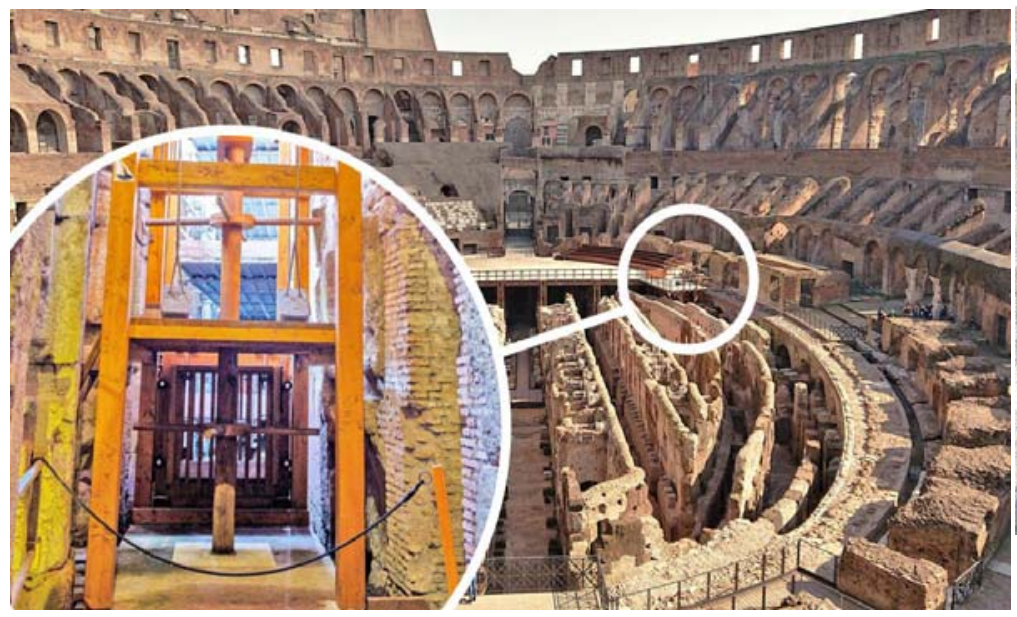

Fig. 15. The hypogeum, the under-floor complex.

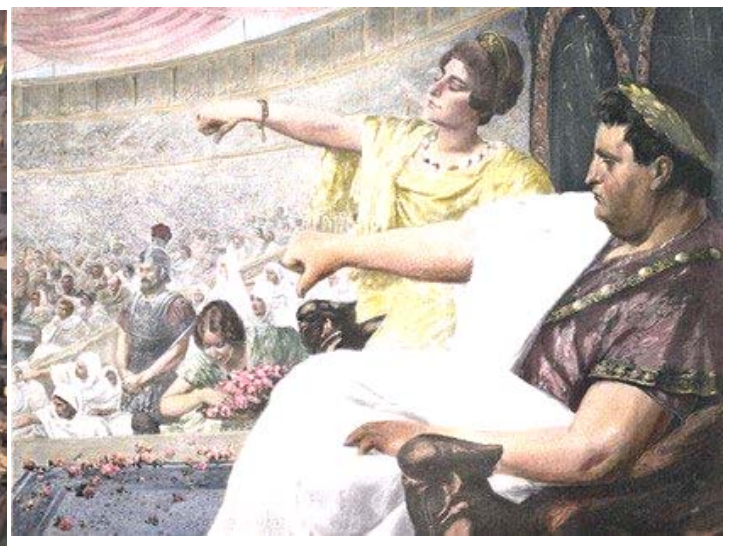

Fig. 16. The Roman emperor Nero. The first century AD in Rome.

Hidden from the 50,000 bloodthirsty fans 2,000 years ago, the basement has been opened to visitors for the first time, offering a close-up look at the secret heart of the historic venue. The cramped corridors beneath Rome's Colosseum were a frightening place where gladiators prepared for combat and slaves pushed wild beasts into lifts to propel them into the arena above. "This was the backstage of the Colosseum, a monument within a monument which has now been fully restored and reopened," Alfonsina Russo, director of the Colosseum, said (2021) [20], see video [49].

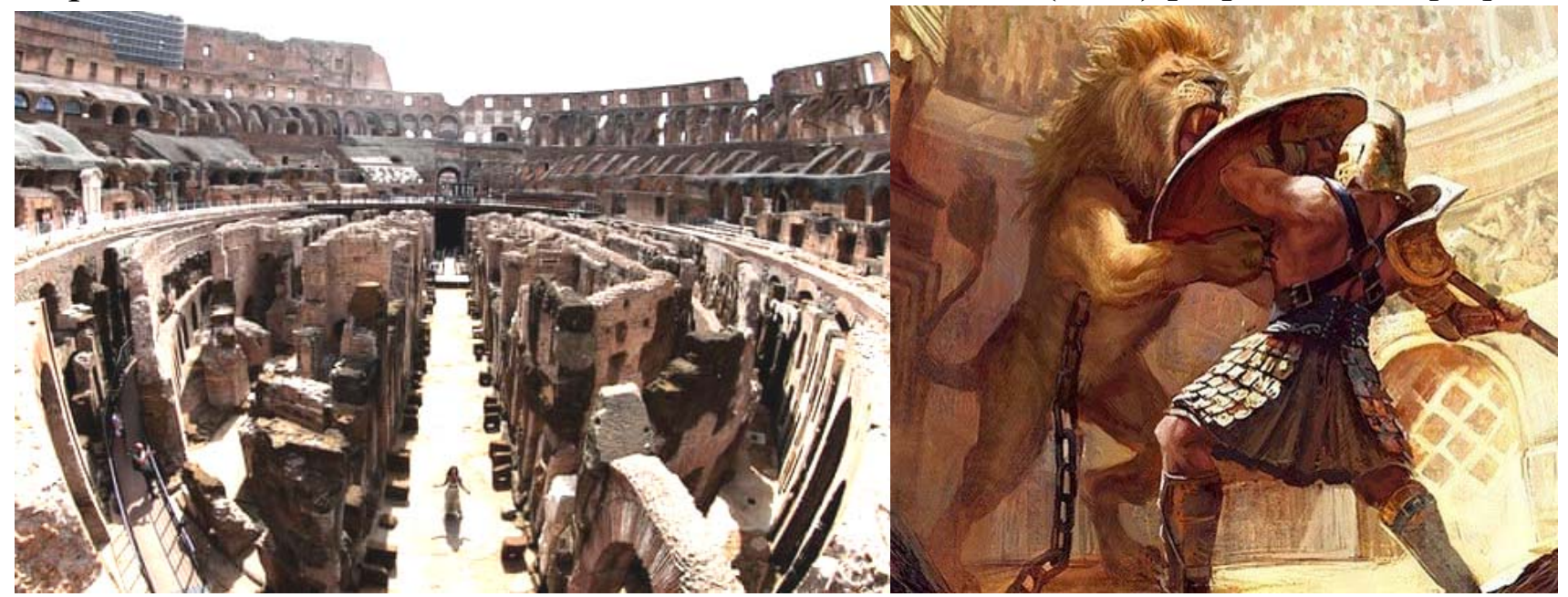

Fig. 17. The hypogeum.

Fig. 18. Gladiator Carpophorus.

The Roman amphitheatre, completed under Emperor Titus in AD 80, once had a wooden floor covered with sand that was built on top of a network of tunnels and rooms where gladiators and animals waited before entering the arena. But the floor was removed in the late $1800 \mathrm{~s}$ when archaeologists began to excavate the subterranean levels of the structure. The underground area was opened to the public in 2010 and visitors can also see the tunnels when they look down from what were the tiered rows of seats [18], see the video [19].

The new, hi-tech stage will be able to quickly cover or uncover the underground networks below, allowing them to be protected from the rain or to be aired out. The idea of rebuilding the arena of the Colosseum, the biggest amphitheatre 
constructed during the Roman empire, was first mooted by archaeologist Daniele Manacorda in 2014. The idea was supported by Franceschini, who said at the time the arena could also be used for re-enactments of the gladiator battles. In Roman times, crowds would fill the Colosseum to watch gladiators defeat animals including bears, tigers, elephants and rhinoceros $[18 ; 54]$.

Milan Ingegneria, a structural engineering and architecture firm, has won an $€ 18.5 \mathrm{~m}(£ 16 \mathrm{~m})$ bid to build and install a retractable arena floor that will allow visitors "to see the majesty of the monument" from its centre, culture minister Dario Franceschini said. The project is expected to be completed within the next two years."In 2023, we will have the splendour of the Colosseum with its arena again,"

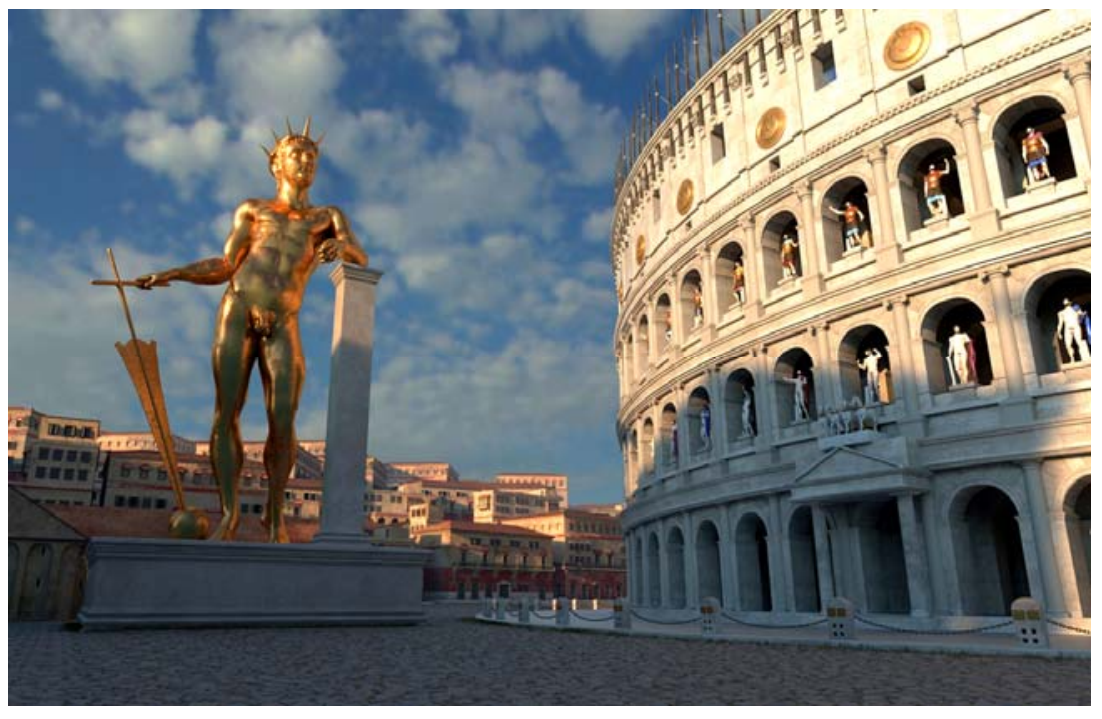

Fig. 19. The Colossus of Nero.

Franceschini added [18].

But why was it decided to call it the Colosseum? The Colosseum is the most visited attraction in Rome, originally called the Flavian Amphitheatre; yet Colosseum is a nickname from the middle ages recalling not the size of the gladiatorial arena but of an entirely different monument - a gigantic bronze statue so-called The Colossus of Nero (Fig. 19, 21). Ancient writers tell of an enormous bronze statue commissioned by the narcissistic and crazed young emperor Nero for the entrance of his party palace the 'Domus Aurea' (built after the 'Great Fire' of 64 AD). Tradition has it that the statue was of the emperor Nero (Fig. 16) posing as the sun god Sol, an attempt by Nero to grasp divine status while still living. There are many stories about the statue, its size, the face (Fig. 20) and what happened to it. Several emperors changed the face of the statue, adding their own likeness or removing that of an earlier emperor. Yet despite its association with an apparently crazed and despotic ruler the statue endured for at least three hundred years [7], see video [46].

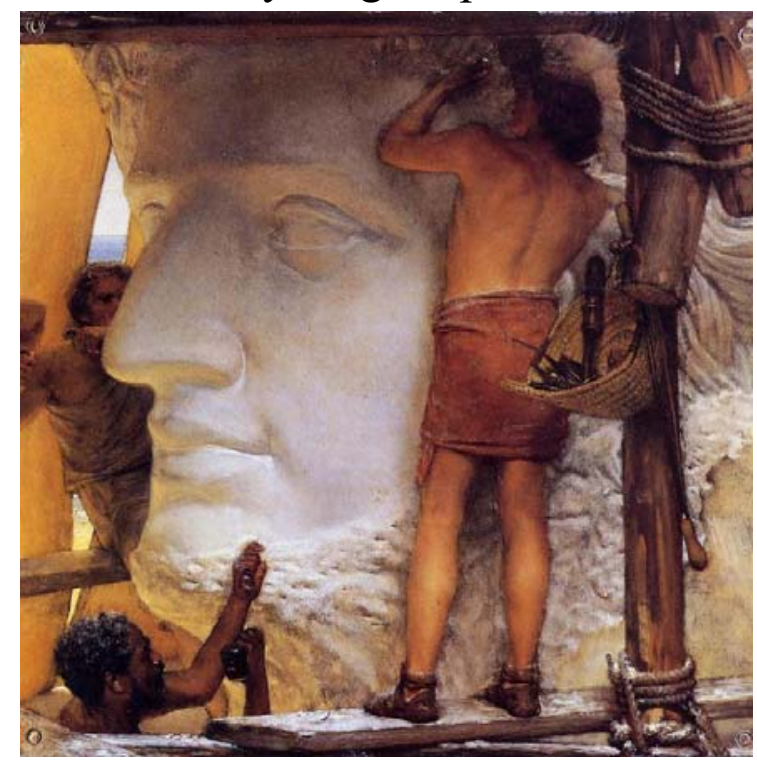

\section{Fig. 20. The face of The Colossus of Nero.}

Three main sources are Pliny, Suetonius and Cassius Dio, all writing at different times and they do not agree. Pliny tells us he visited Zenodorus' workshop and so perhaps is the most reliable. 'Summoned to Rome by Nero, he made a colossus 
$106 \frac{1}{2}$ feet tall'; the text is corrupted, some claim it reads 119 feet, or it may have been copied wrongly by later writers. Suetonius tells us it was 120 -foot-tall and Cassius Dio writing over a hundred years later tells us one hundred feet high. The statue wore a crown with rays (of sun) coming out of it - was this included in the height of the colossus? (see the video [60] 1:20 min).

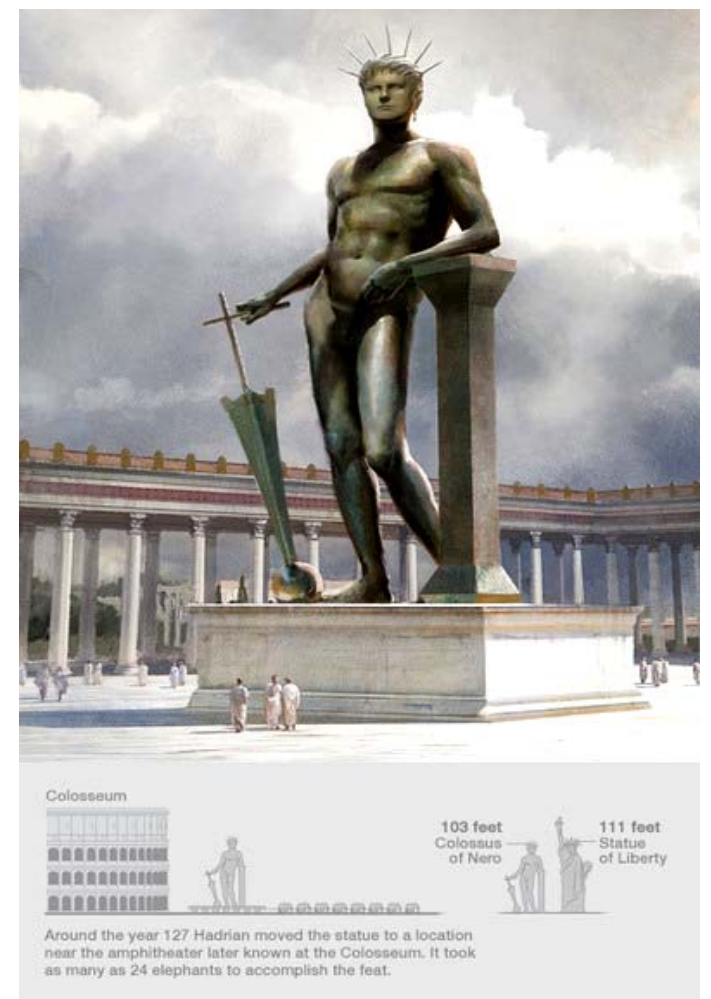

Over fifty years later Hadrian placed the statue on a marble covered base next to the Flavian Amphitheatre. So, the colossus was somewhere between $106 \mathrm{ft}$ and $120 \mathrm{ft}$ with or without its crown and base [7], Fig. 19, 21.

The last mention of the statue is in 354 $\mathrm{AD}$ and many believe it was destroyed in the sack of 410, or brought down by earthquakes shortly after. Yet a statement from the 7th century Saint Venerable Bede (Fig. 22), English Benedictine monk suggests it may have still been there in

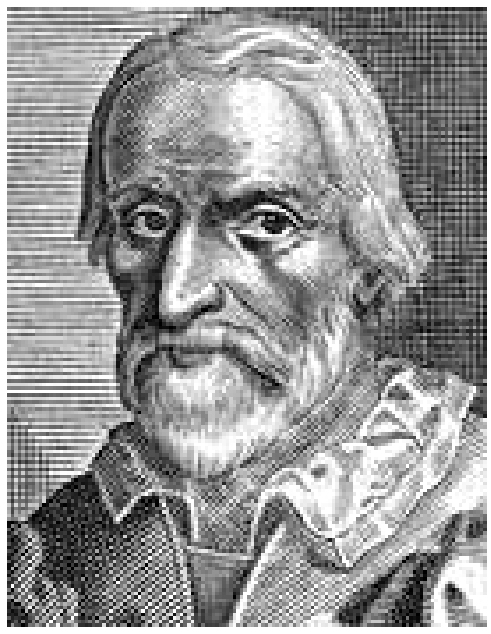

Fig. 21. 'So long as the Colossus stands, Rome shall stand...'

Fig. 22. Portrait of Saint Bede. medieval times: 'So long as the Colossus stands, Rome shall stand; when the Colossus falls, Rome too shall fall; and when Rome falls, so falls the world' [7]. (Fig. 21).

St Bede ['bi:da] - also known as the Venerable Bede - is widely regarded as the greatest of all the Anglo-Saxon scholars. He wrote around 40 books mainly

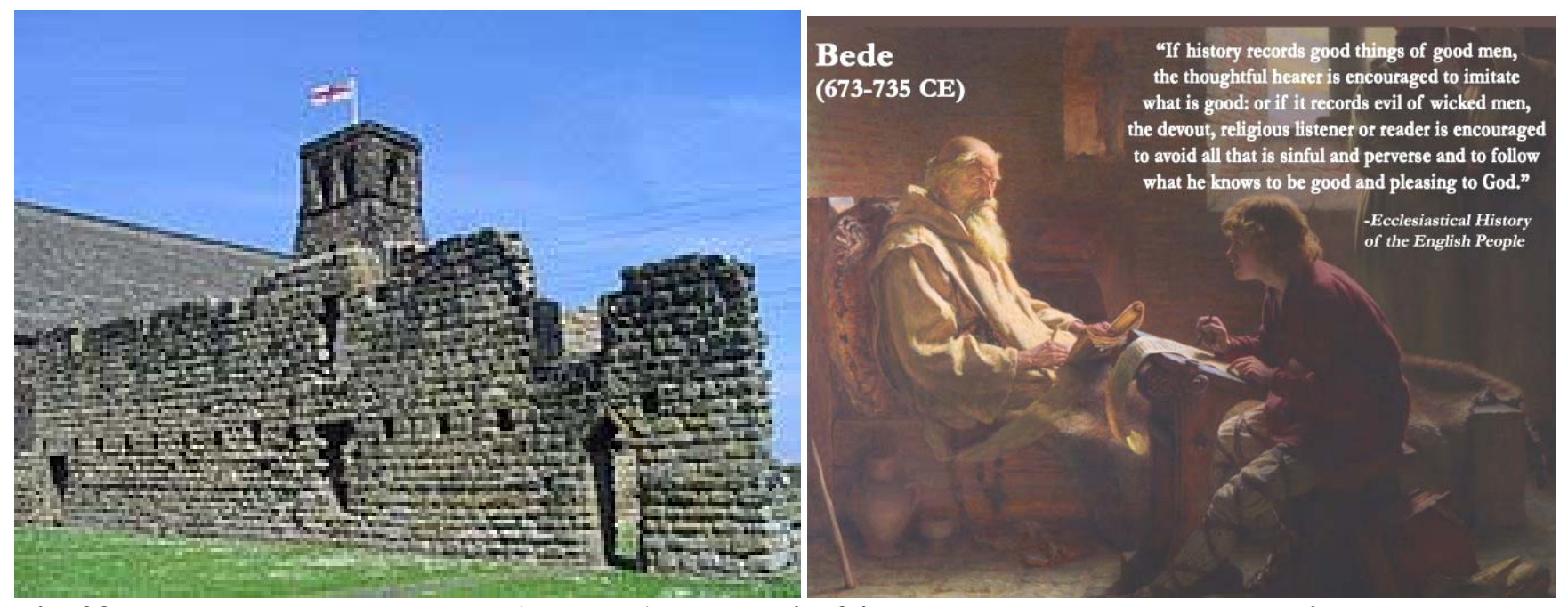

Fig. 23. The monastery at Jarrow (England).

Fig. 24. The Venerable Bede Translating the Last Chapter of St John' (1926) by James Doyle Penrose. 
dealing with theology and history. The Venerable Bede (673 AD-735 AD) was probably born in Monkton, Durham. Nothing is known of his family background. At the age of seven he was entrusted to the care of Benedict Biscop, who is $674 \mathrm{AD}$ had founded the monastery of St Peter at Wearmouth. In $682 \mathrm{AD}$, Bede moved the monastery at Jarrow (Fig. 23), where he spent the rest of his life. By the age of 19 he had become a deacon and was promoted to priest at 30 . His scholarship covered a huge range of subjects, including commentaries on the bible, observations of nature, music and poetry.

His writings reveal how the values of Christianity were implanted and integrated within the violent warrior society that existed at that time His most famous work, which is a key source for the understanding of early British history and the arrival of Christianity, is 'Historia Ecclesiastica Gentis Anglorum' or 'The Ecclesiastical History of the English People' which was completed in 731 AD. It is the first work of history in which the AD system of dating is used. Written towards the end of his life and dedicated to King Ceolwulf of Northumbria, 'The Ecclesiastical History' represented the culmination of Bede's lifetime's work. In it, not only did he leave a coherent record of the heroic foundation of early Christianity in England, but it also set an example of how this was successfully achieved. Bede is also concerned to show the unity of the English, despite the disparate kingdoms that still existed when he was writing. [14; 10].

Bede died in his cell at the monastery in May 735 AD (Fig. 23, 24).

Today, Bede is widely recognised as the greatest Anglo-Saxon scholar of his day, and by many as the greatest English historian of all time (see videos [43]):

If history records good things of good men,

the thoughtful hearer is encouraged to imitate

what is good: or if it records evil of wicked men,

the devout, religious listener or reader is encouraged

to avoid all that is sinful and perverse and to follow

what he knows to be good and pleasing to God.

(From the preface of Bede's Ecclesiastical History of the English People (and relevant letters), translated by Leo Sherley-Pride, R. E. Latham and D. H. Farmer (Penguin Classics, 2003). URI : https://thehistorianshut.com/2017/08/15/bede-2/)

Also, "a Roman holiday" - entertainment acquired at the expense of others' suffering, or a spectacle yielding such entertainment (Webster's New World College Dictionary, 4th Edition. Copyright $(2010$ by Houghton Mifflin Harcourt. All rights reserved).

"A Roman holiday" (noun):1) a public spectacle or controversy marked by barbarism, vindictiveness, or scandal; 2) pleasure or advantage gained from the discomfort or suffering of others.

(Most material @ 2005, 1997, 1991 by Penguin Random House LLC. Modified entries $(2019$ by Penguin Random House LLC and HarperCollins Publishers Ltd)

We also want to add that an instance in which someone experiences enjoyment on account of someone else's suffering. The expression, first used in this sense in 
Byron's "Childe Harold" (IV, 141) [11; 26] (Fig. 25, 26), derives from the fact that the Roman Empire frequently proclaimed work-free days on which to hold gladiatorial games. "A Roman holiday" can function as a loose equivalent of the German term Schadenfreude, which also means pleasure derived from another person's misfortune [52]:

....He reck'd not of the life he lost nor prize,

But where his rude hut by the Danube lay,

There were his young barbarians all at play,

There was their Dacian mother -- he, their sire,

Butcher'd to make a Roman holiday --

All this rush'd with his blood -- Shall he expire

And unavenged? -- Arise! ye Goths, and glut your ire! [11], Fig. 26, .27.

As we have mentioned earlier in our article, the famous statement of The Venerable Bede 'So long as the Colossus stands, Rome shall stand...' is considered in the context of studying the Colosseum in Rome. Therefore, note that these words were remembered by Lord Byron in his poem "Childe Harold's Pilgrimage" (1812-1818) in

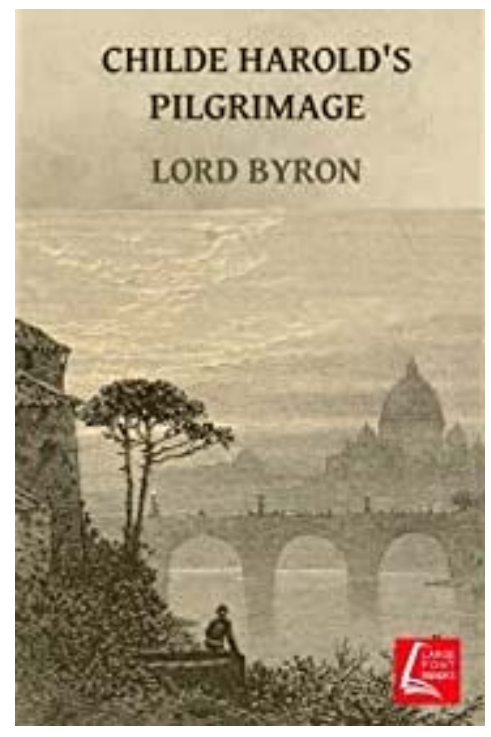

Canto IV (Fig. 27):

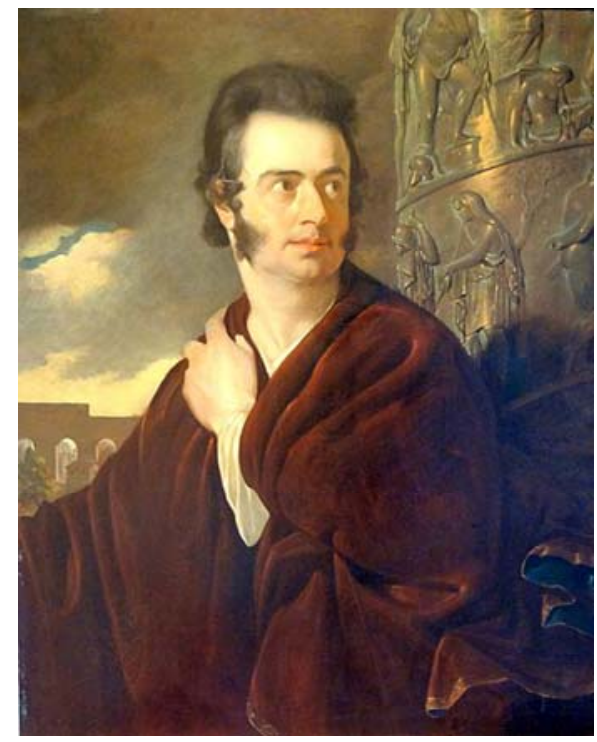

Fig. 26. Portrait of Lord Byron (1814).
Fig. 25. Childe Harold's Pilgrimage ( ed. 2018) by Lord Byron.

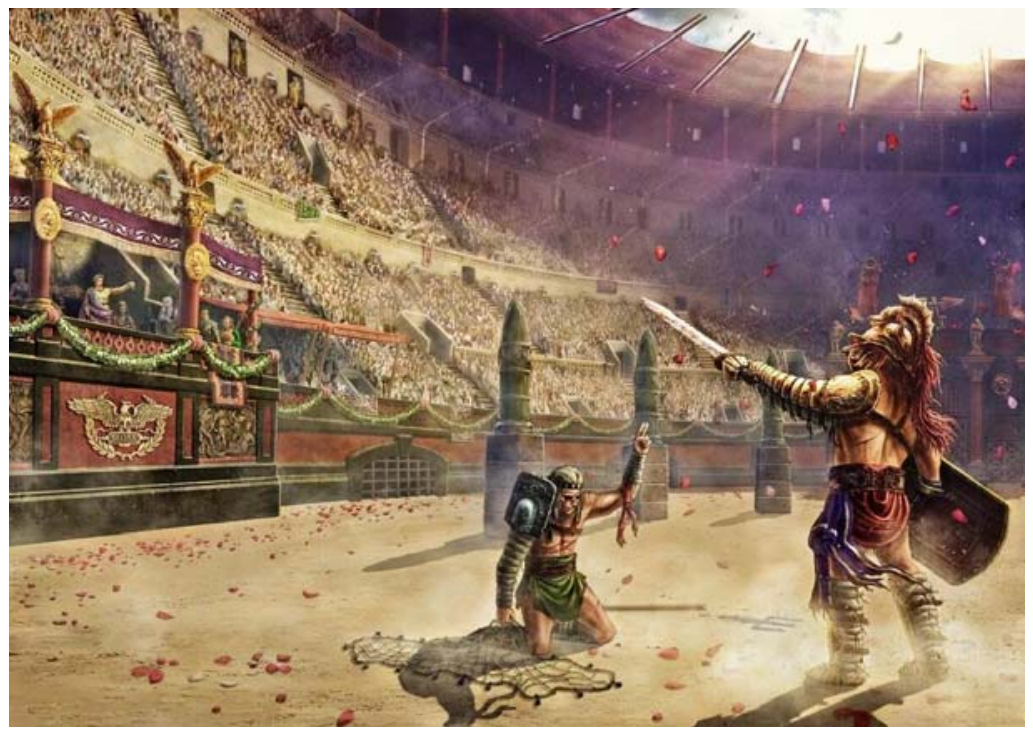

Fig. 27. A Roman holiday in the Coliseum.

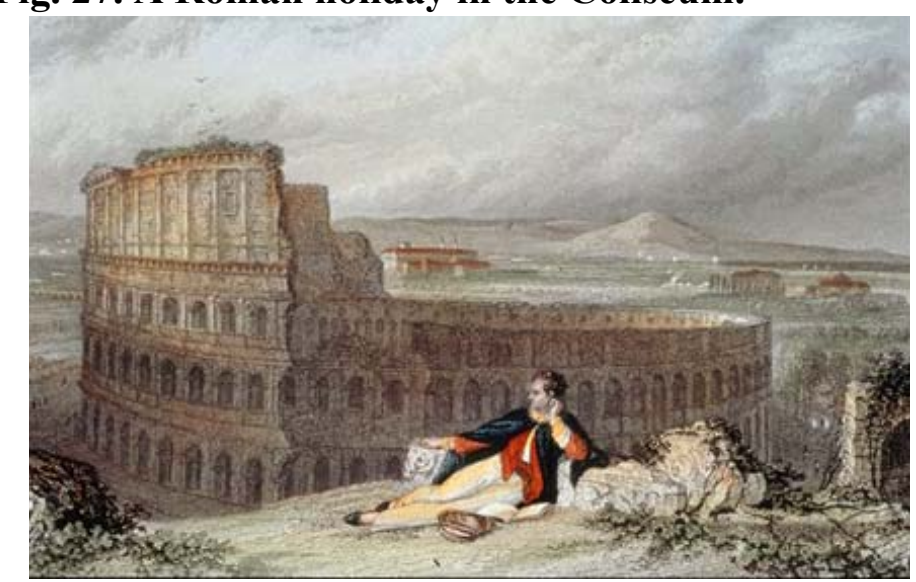

'While stands the Coliseum, Rome shall stand; When falls the Coliseum, Rome shall fall; And when Rome falls -- the World.' From our own land

Thus spake the pilgrims o'er this mighty wall In Saxon times, which we are wont to call Ancient; and these three mortal things are still On their foundations, and unalter'd all; Rome and her Ruin past Redemption's skill, The world, the same wide den -- of thieves, or what ye will... [11;27], Fig. 28.

Fig. 28. Lord Byron contemplating the Coliseum (about 1817) by Thomas Phillips. 
The Colosseum was built by the emperor Vespasian (see videos $[57 ; \mathbf{6 1} ; \mathbf{5 1}]$ ), with construction starting in 72 BC, ending eight years later. His son, Titus (Fig. 19), inaugurated the Colosseum with 100 days of games, which included mock naval battles (in about one metre of water ([videos $[48 ; \mathbf{1 6}]$ ), execution of animals, and gladiator combat. According to ancient historian Eutropius, 5,000 animals were killed during those inaugural games (see the video [49]).

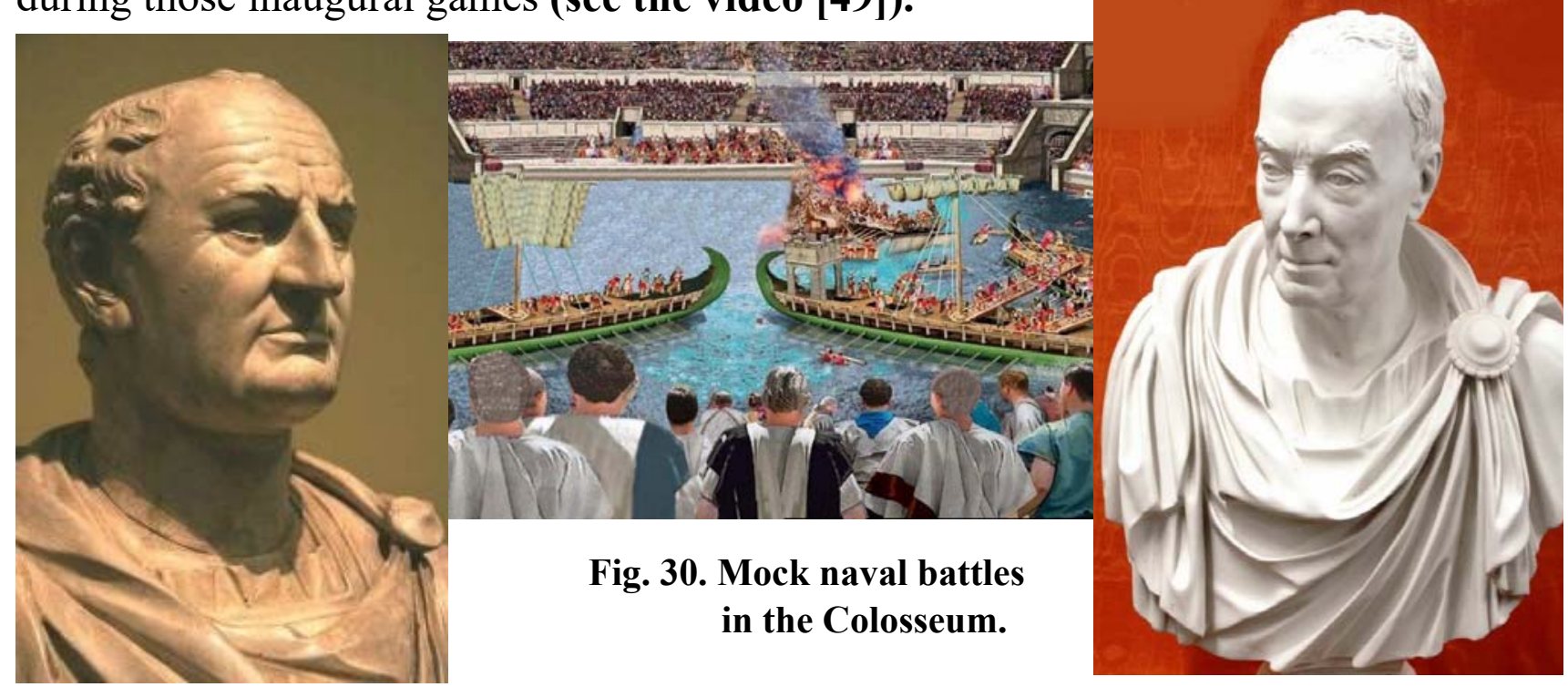

Fig. 29. The emperor Vespasian.

Fig. 31. The emperor Titus.

In its heyday, the amphitheater could host between 50,000 and 70,000 spectators [30].

But the rivalrous brother of Titus, Domitian (emperor 81-96), was quick to have a basement built with ring-formed walls and narrow passages. A series of winches and the capstans would have allowed teams of slaves to pull in unison and hoist heavy animals from the basement to the main arena, and this machinery has been reconstructed. After the fall of the Roman Empire, it was used as housing and as source of material for other construction work around the city [30], see videos [14].

And now, at about the centre of the Roman Forum in Rome, stand three pillars that support the remains of a horizontal frieze. This is what remains of a temple dedicated to the defiled Emperor Vespasian and his

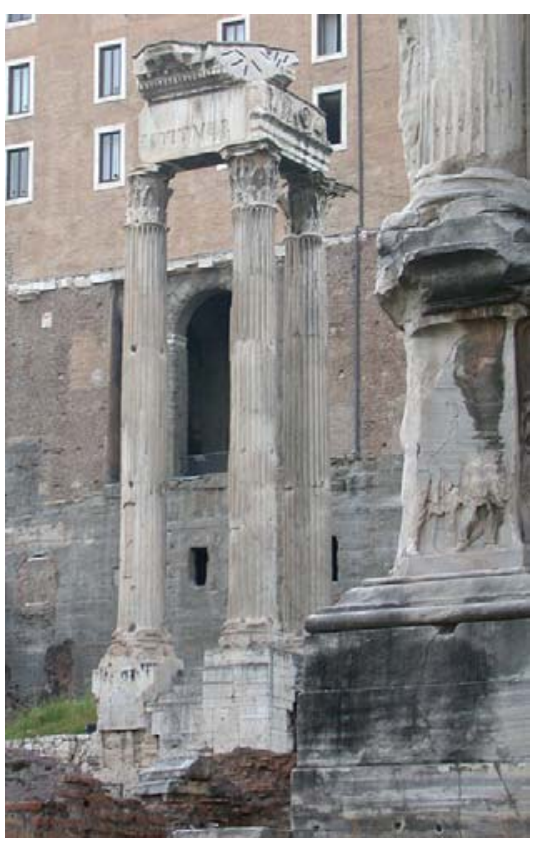
defiled son Titus, who both ruled Fig. 32. The Temple of Emperor Vespasian and his son Titus. at the end of the 1st century AD. It was their son and brother, the Emperor Domitian, who erected this temple. The building thus illustrates a key step in the design of the empire: the deification of Vespasian and Titus after their death [50].

Award-winning historian Bettany Hughes is on a mission that will take us across Italy's ancient sites and into the psyches of the emperors, gladiators, and generals of the Roman Empire in documantary Eight Days That Made Rome (2017). Explore the rise and fall of one of history's most extraordinary reigns, defined by 
eight critical days. From the defeat of the Carthaginian Empire to Julius Caesar's crossing the Rubicon River to Constantine's conversion to Christianity, explore this remarkable period and meet its key figures [14].

At last. Everything about the movie fascinated us. More importantly though, it was the effortless charm of the film Roman Holiday that struck us greatly. This film though, really does belong to Audrey Hupbern $[22 ; 23]$. Her performance at the age

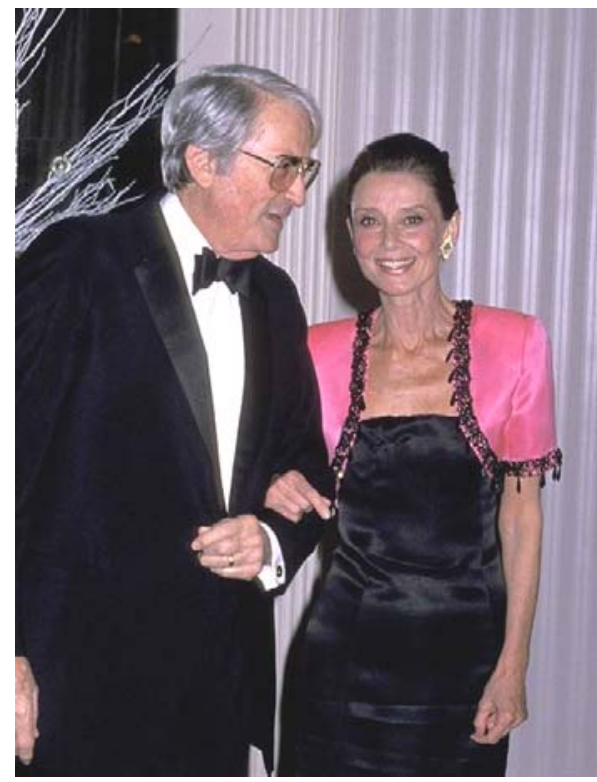
of 23 was just the perfect mix of sprightly innocence and delightful charisma that even the simplest things are a pleasure to watch (Fig. 34, 36). We think the simplicity of the story, as well as the lovely mix of lighthearted humour and sweet poignancy, make Roman Holiday

(1953) truly unique.

To sum up, when we think about this movie, probably the first scene that comes to our minds is the Vespa scene. The iconic Vespa ride (Fig. 3, 4,36) that Fig. 33. G. Peck and A. Hupbern (1988). made us all dream of having a similar experience, especially in the moment in which the Colosseum is the background. This is a stunning view that is worth seeing at least once in life.

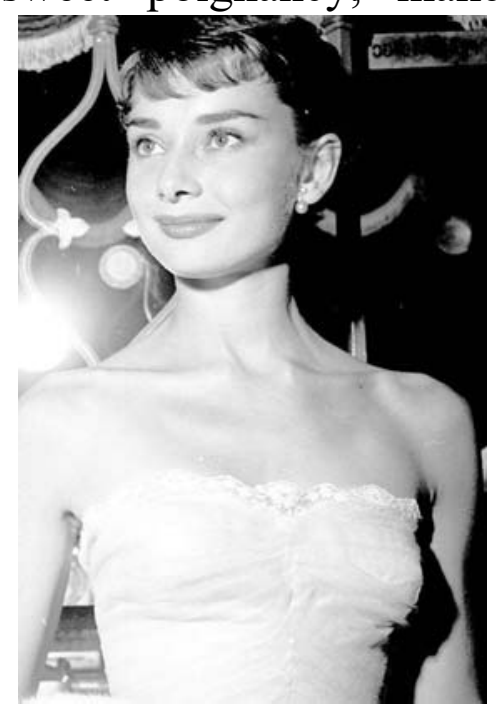

Fig. 34. Audrey Hupbern at the premiere of 'Roman Holiday' (1953).

During the duration of the Roman Empire the Colosseum was restored on various occasions because of the many fires and earthquakes that hit it over the years. The history behind this work of architectural splendor is absolutely fascinating and well-worth learning about (Fig. 35).

The film Roman Holiday (1953) is a great guide for everybody who loves traveling, watching movies and series and visiting filming locations.

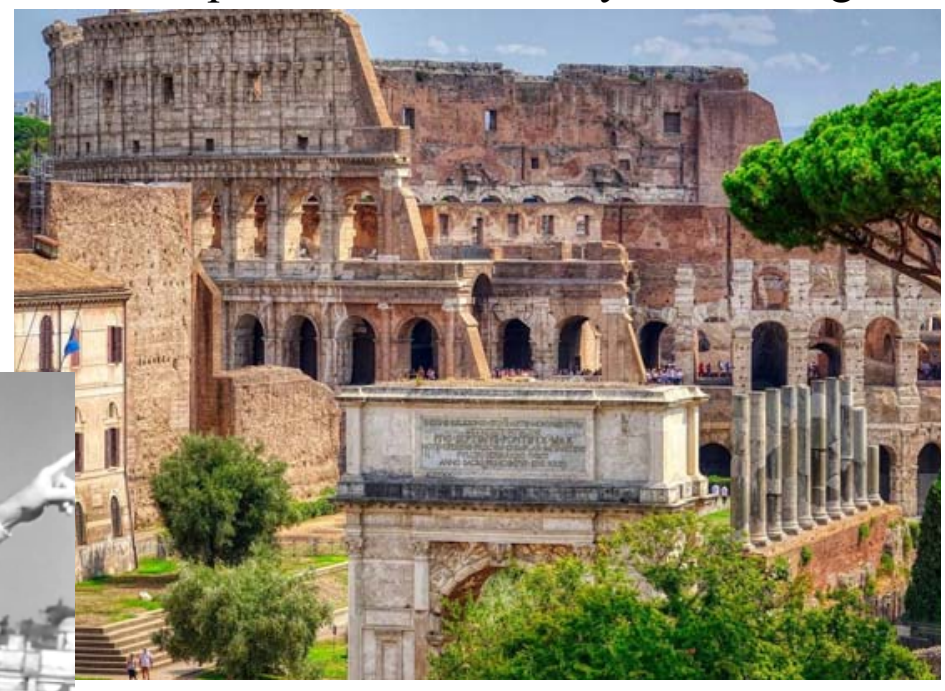

Fig. 35. The Colosseum, Rome.

Fig. 36. Roman Holiday (1953). The movie duye G. Peck and A. Hupbern. The iconic Vespa ride around Rome. 


\section{References}

1. Ancient Colosseum: A Virtual reality experience with Oculus Rift. URI : https://www.youtube.com/watch?v=bAWTJO6oz-o

2. Ancient Rome reconstructed. URI : https://www.youtube.com/watch?v=OfwoX3Vyjua

\section{(from 15.10 min.)}
3. Childe
Harold's
Pilgrimage.
Canto
IV.
URL :

https://petercochran.files.wordpress.com/2009/03/chp4.pdf

4. Chornyi M. 'Roman Holiday' Filming Locations. URL :

https://www.recenzent.org.ua/roman-holiday-filming-locations/
5. Colosseum
reconstructed $\mathrm{c}$.
by
archeolibri
s.r.l.
URL :

https://www.youtube.com/watch? $\mathrm{v}=8 \mathrm{sLy} 5 \mathrm{VCMuKM}$

6. Colosseum, Rome

[HD].

URL :

https://www.youtube.com/watch?v=4WphJnTNGPM\&t=539s With subtitles

7. Colossus of Nero. URI : https://colosseum.info/colossus-of-nero/

8. Eyewitness Travel Family Guide to Italy: Rome and Lozio. London : Dorling Kindersley Publishing Pvt

Ltd,

2014.

https://books.google.com.ua/books?id=FHpAAwAAQBAJ\&pg=PT198\&lpg=PT198\&dq=video+The+ Colosseum + in + the + film $+\ll$ Roman + Holiday $» \&$ source= $=$ l\&ots $=$ bp $8 I n-$

i1SS\&sig=ACfU3U2dWnWgSjjya71BvVNfzNGad9t3Lg\&hl=ru\&sa=X\&ved=2ahUKEwi78aSCr5 XyAhVEgf0HHWD5A3AQ6AF6BAgGEAM\#v=onepage $\& q=$ video $\% 20$ The $\% 20$ Colosseum $\% 20 \mathrm{in}$ $\% 20$ the $\% 20$ film $\% 20 \ll$ Roman $\% 20$ Holiday»\&f=false

9. Fesyna A., Pet'ko L., Turchynova G. Spanish Steps in Rome and movie Roman Holiday (1953) : Abstracts of the $\mathrm{V}^{\text {th }}$ International Scientific and Practical Conference «Theoretical and scientific bases of development of scientific thought» (Rome, February 16-19, 2021). Italy, Rome : Bookwire $^{\mathrm{TM}}$. 2021. Pp. 152-161.

URL http://enpuir.npu.edu.ua/handle/123456789/33239

10. Johnson Ben. The Venerable Bede. URI : https://www.historicuk.com/HistoryUK/HistoryofEngland/The-Venerable-Bede/

11. George Gordon, Lord Byron. Childe Harold's Pilgrimage. Canto the Fourth. URI : http://knarf.english.upenn.edu/Byron/charold4.html

12. Herasymchuk Y., Pet'ko L. English Romantic Poets John Keats and Percy Bysshe Shelley in Rome and The Legendary Movie "Roman Holiday" // Topical issues of practice and science: abstracts of the XXVI ${ }^{\text {th }}$ International scientific-practical conference (London, 18-21 May 2021). Great Britain. London: Bookwire $^{\mathrm{TM}} .2021 .835$ p. Pp. 138-149. URI : http://enpuir.npu.edu.ua/handle/123456789/34070

13. Herasymchuk Y., Pet'ko L., Turchynova G. The Spanish Square in Rome and movie Roman Holiday. Multidisciplinary research : abstracts of the XIV ${ }^{\text {th }}$ International scientific-practical conference (Bilbao, 21-24 December 2020). Spain. Bilbao: International Science Group, 2020. Pp. 113-123.

URI : http://enpuir.npu.edu.ua/handle/123456789/32566
14. History.
The
Venerable
Bede
(673 AD-735 AD).
URI : http://www.bbc.co.uk/history/historic_figures/bede_st.shtml

15. Hopkins Keith. The Colosseum: Emblem of Rome. BBC. History. URI : http://www.bbc.co.uk/history/ancient/romans/colosseum_01.shtml

16. How Romans flooded the Colosseum for sea battles. URI : https://www.ted.com/talks/janelle_peters_how_romans_flooded_the_colosseum_for_sea_battles/tra nscript

17. How the Roman Colosseum Was Built. URL :

https: //www.youtube.com/watch?v=09meiYkTsBo\&t=32s

18. Giuffrida Angela. Rome's Colosseum to gain hi-tech arena floor. The Guardian. Sun 2 May 2021. URL : https://www.theguardian.com/world/2021/may/02/rome-colosseum-to-gain-hitech-arena-floor 
19. Inside and Underground Secrets of the Colosseum. Rome Travel Italy. URI : https://www.youtube.com/watch?v=EEPzsLHkRns

20. Kington Tom. Colosseum's lifts return from depths of history. The Times. Saturday June 26 2021. URL : https://www.thetimes.co.uk/article/colosseums-lifts-return-from-depths-of-history$5 \mathrm{p} 8 \mathrm{pnkn} 7 \mathrm{p}$

21. Know about the magnificent infrastructural work of imperial Rome, especially Roman masonry. URI : https://www.britannica.com/video/187678/infrastructure-masonry-Rome-Roman

22. Kirilchuk N., Pet'ko L. The Style Icon And The Rose "Audrey Hepburn": Abstracts of the IV ${ }^{\text {th }}$ International Scientific and Practical Conference «Prospects and achievements in applied and basic sciences» (Budapest, February 9-12, 2021). Hungary. Budapest : Bookwire $^{\mathrm{TM}}$. 2021. Pp. 57-72.

URL : http://enpuir.npu.edu.ua/handle/123456789/33212

23. Klymenko N., Pet'ko L. The image of British actress Audrey Hepburn in a rose named after "most beautiful woman of all time". Topical Issues of Science and Practice : abstracts of VII Sientific and Practical Conference (London, 02-06 November 2020). Great Britain, London : International Science Group, 2020. 781 p. Pp. 42-51.

24. Kruhlova A., Pet'ko L. "Oh, Tiber, Father Tiber!" and movie Roman Holiday (1953) : Abstracts of the $\mathrm{V}^{\text {th }}$ International Scientific and Practical Conference «Theoretical and scientific bases of development of scientific thought» (Rome, February 16-19, 2021). Italy, Rome : Bookwire $^{\mathrm{TM}}$. 2021. Pp. 162-171.

URL http://enpuir.npu.edu.ua/handle/123456789/33253

25. Kruhlova A., Pet'ko L. "Roman Holiday" (1953) filming locations in Rome: Tiber River // Trends in the development of modern scientific. Abstracts of XXXI International Scientific and
Practical
Conference.
Vancouver,
Canada.
2021.
Pp. 102-116.

URI : ttp://enpuir.npu.edu.ua/handle/123456789/34665

26. Lord Byron. Childe Harold's Pilgrimage. Publisher: CreateSpace Independent Publishing Platform, 2018. 128 p.

27. Childe Harold's Pilgrimage Canto IV Full Audiobook by George Gordon by Narratives.

URI : https://www.youtube.com/watch?v=UU1VEFSubA8

28. Machak V., Pet'ko L. The Pantheon. Rose Petals and the Film "Roman Holiday" // Science and practice, problems and innovations: Abstracts of VII International Scientific and Practical Conference. Ottawa, Canada, 2021, pp. 53-68.

URL : http://enpuir.npu.edu.ua/handle/123456789/33285

29. Melnychuk A., Pet'ko L. Palazzo Brancaccio in the film "Roman Holiday" (1953) // Interaction of society and science: problems and prospects : abstracts of the XXX International Science Conference (London, May 18-21, 2021). Great Britain. London : Bookwire ${ }^{\mathrm{TM}}$. 2021. Pp. 126-139. URI : http://enpuir.npu.edu.ua/handle/123456789/34579

30. Messia Hada. Rome's Colosseum opens its underground for the first time in its history. $C N N$ Travel. $25^{\text {th }}$ June 2021. URI: https://edition.cnn.com/travel/article/colosseum-rome-undergroundhypogea/index.html

31. Pet'ko Lyudmila. Teaching methods and the formation of professionally oriented foreign language learning environment in conditions of university. Intellectual Archive. 2016. Volume 5. No. 4 (July/August). Toronto : Shiny Word Corp., Canada. PP. 73-87.

32. Ray Sanjana. The Colosseum Opens Its Underground Tunnels to Tourists. National Geographic Traveller India. June 30, 2021. URI : http://www.natgeotraveller.in/the-colosseumopens-its-underground-tunnels-to-tourists/

33. Rome, Italy: The Colosseum. URI :

https://www.youtube.com/watch?v=xaSbYIeqGWg

34. Roman Holiday (1953). URL : http://filmatika.ru/english_movies/roman-holiday/ with

\section{English subtitles}

35. Roman Holiday, a movie that made the History of Cinema. URI : https://www.romeprivateguides.com/en/blog/about-rome/roman-holiday.html 
36. Roman Holiday: movie. 1953 (USA). Starring: Gregory Peck, Audrey Hepburn. Director: William Wyler. URI : https://www.dailymotion.com/video/x3rp5md (in English)

37. Roman Holiday (1953). Film locations then and now. URL:

https://www.youtube.com/watch?v=6YIs8xaKCOA

38. Roman Holiday (1953) - (Movie Clip) Scooter. URI :

https://www.tcm.com/video/1066945/roman-holiday-1953-scooter

39. Roman Holiday (1953) Script. URI :

http://www.script-o-rama.com/movie_scripts/r/roman-holiday-script-transcript.html

40. Roman Holiday (1953). Spoilers for Roman Holiday, Sabrina, Breakfast at Tiffany's and

Spartacus. URI : http://hal0000.blogspot.com/2009/02/roman-holiday-1953.html

41. Roman Holiday (1953). The Blonde at the Film. A fresh look at old films. November 21,

2013. URI : https://theblondeatthefilm.com/2013/11/21/roman-holiday-1953/

42. Sohini Das Gupta. On a Roman Holiday Trail. National Geographic Traveller India.

August 23, 2019. URL : http://www.natgeotraveller.in/on-a-roman-holiday-trail/

43. St Bede. URI : https://www.youtube.com/watch?v=YfJa-fwB02I

44. Stabiner Karen. In Rome, Using 'Roman Holiday' as a Guide. New York Times. Oct. 18,

2016. URI : https://www.nytimes.com/2016/10/23/travel/roman-holiday-film-rome-italy-hepburnpeck.html

45. The Colosseum in the film «Roman Holiday». URL: https://youtube/dhJN1RLR1jI

46. The Colosseum Virtual Walking Tour in 4k. URL :

https://www.youtube.com/watch? $\mathrm{v}=\mathrm{eJeF} 7 \mathrm{hDB} 0 \mathrm{UA}$

47. The glory of Ancient Rome. All parts. Documentary. Collection. URI:

https://www.youtube.com/watch?v=ZxRZBtMktHc

48. The Great Flood: Could the Colosseum Host Gigantic Sea Spectacles? | Blowing Up

History. URI : https://www.youtube.com/watch?v=xbOAXAaao0o

49. The Story Behind the Colosseum's Greatest Battle. URI :

https://www.youtube.com/watch? $\mathrm{v}=$ fbhuqovrrak

50. The Temple of Emperor Vespasian and his son Titus. URI :

http://en.cityzeum.com/p/the-temple-of-emperor-vespasian-and-his-son-titus

51. The Untold Story Of Emperor Vespasian | Vespasian | Odyssey. URI :

https://www.youtube.com/watch? $\mathrm{v}=\mathrm{bUdotxA} 0 \mathrm{ws} 8$

52. Top definition Roman holiday. URI :

https://www.urbandictionary.com/define.php?term=Roman\%20holiday

53. Top 10 Famous Ancient Roman Gladiators. URL :

https://www.youtube.com/watch? $=-56$ thbCUnT4\&t $=10 \mathrm{~s}$

54. Top 10 Famous Ancient Roman Gladiators (text format). URL :

https://www.ancienthistorylists.com/rome-history/top-10-famous-ancient-roman-gladiators/

55. Traveling through the movies - Roman Holiday. URL:

https://tvortravels.wordpress.com/2013/04/28/traveling-through-the-movies-roman-holiday/

56. Turchynova G, Pet'ko L., Holovko T. Studying Gardens of the World with Students of

Higher Education Establishments. Intellectual Archive. Toronto: Shiny Word.Corp. (Canada). 2020.

Vol. 9 (October/December). No. 4. Pp. 94-107.

DOI: 10.32370/IA_2020_12_12

57. Vespasian: Savior of Rome \& Father of the Colosseum. URI :

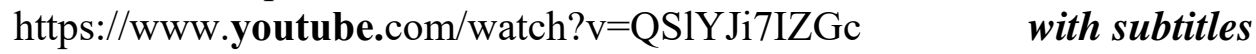

58. Vynohradova N., Pet'ko L. 'Roman Holiday' filming locations in Rome: Trinità dei Monti : Abstracts of the $\mathrm{V}^{\text {th }}$ International Scientific and Practical Conference «Theoretical and scientific bases of development of scientific thought» (Rome, February 16-19, 2021). Italy, Rome : Bookwire $^{\mathrm{TM}}$. 2021. Pp. 172-185.

URL : http://enpuir.npu.edu.ua/handle/123456789/33252

59. Yudytskyi B., Pet'ko L. Roman Forum and "Roman Holiday", a movie that made the

History of Cinema // Current issues of science and education: Abstracts of XIV International 
Scientific and Practical Conference (Rome, March 23-26, 2021). Italy, Rome : Bookwire ${ }^{\mathrm{TM}} .2021$, pp. 56-70.

URL : http://enpuir.npu.edu.ua/handle/123456789/33556

60. What happened to the missing half of the Colosseum? URI : https://www.youtube.com/watch?v=hIO8chsH_7U

61. Why Romans Adored Emperor Vespasian | Imperium: The Path To Power| Timeline. URI : https://www.youtube.com/watch?v=r72X5oUPTwM

\section{Translation of the Abstract to the Author's Language}

УДК 378.147:811.111]:791.5

Турчинова Г., Петько Л., Григорук Л. Колізей у фільмі «Римські канікули» (1953).

Стаття присвячена Колізею та фільму «Римські канікули» (1953, США). Це - перший голлівудський фільм, який був знятий і повністю оброблений в Італії. В історичному центрі міста мало що змінилося. Історія про принцесу Анну (актриса Одрі Хепберн), яка приїжджає 3 офіційним візитом до Риму і тікає одного вечора 3 посольства, та американського журналіста (Грегорі Пек), який дарує принцесі Анні захоплюючий день відпочинку в Римі, наповнений незабутніми враженнями. Ми бачимо прекрасні краєвиди Риму, відомі архитектурні пам'ятки, вулиці, площі, фонтани і мости. Місто - музей. Тож, коли Одрі Хепберн оглядає Колізей, вона справді оглядає Колізей. У фільмі "Римські канікули" принцеса Анна міцно тримається Джо, коли вони мчать дорогами повз знаменитий Колізей. Кінозірки, що їхали на «Веспі», створили знаковий кінопостер до фільму, під час важливої ери для італійського кіномистецтва.

Автори статті пропонують інноваційний підхід до формування професійно орієнтованого іншомовного освітнього середовища шляхом вивчення зйомок шедевра світового кінематографа «Римські канікули» (1953, США), на прикладі Колізею. Це типовий приклад, скопійований по всій імперії: надзвичайно декоративний зовнішній вигляд будівлі ззовні та всередині з підземними кімнатами під підлогою арени (гіпогеніум), щоб сховати людей, тварин та реквізит, поки вони чекають своєї участі у гладіаторських боях. «Театр смерті». Згадується найвідоміший англійський історик Беда, поема лорда Байрона "Паломництво Чайльда Гарольда", гладіатори.

Ключові слова: університет, професійно орієнтований іншомовний освітній простір, студенти, фільм «Римські канікули» (1953, США), Колізей, гіпогеум, англійський історикБеда Преподобний, лорд Байрон «Паломництво Чайльда Гарольда», гладіатори. 